\title{
Analysis of the improved water-resistant properties of plaster compounds with the addition of plastic waste
}

\author{
Alejandra Vidales-Barriguete ${ }^{\mathrm{a}, *}$, Evangelina Atanes-Sánchez ${ }^{\mathrm{b}}$, Mercedes del Río-Merino ${ }^{\mathrm{c}}$, \\ Carolina Piña-Ramírez ${ }^{\mathrm{c}}$ \\ ${ }^{a}$ Universidad Politécnica de Madrid, Escuela Técnica Superior de Edificación, Departamento de Tecnología de la Edificación, Spain \\ ${ }^{\mathrm{b}}$ Universidad Politécnica de Madrid, Escuela Técnica Superior de Ingeniería y Diseño Industrial, Departamento de Ingeniería Mecánica, Química y Diseño Industrial, Spain \\ ${ }^{c}$ Universidad Politécnica de Madrid, Escuela Técnica Superior de Edificación, Departamento de Construcciones Arquitectónicas y su Control, Spain
}

\section{H I G H L I G H T S}

- Compounds are made of gypsum and plastic cable waste as aggregates.

- Water absorption and retention capacity are lower in compounds with plastic waste.

- Plastic cable waste addition decreases the total pore volume maintaining the size.

- Plastic cable waste in gypsum matrices decreases the use of natural resources.

- Compounds with plastic cable waste minimise environmental impacts in construction.

\section{Keywords:}

Moisture

Impermeability

Plaster

Plastic waste

Hygrothermal

Gypsum with additives

\begin{abstract}
A B S T R A C T
The aim of this article is to analyse the water-resistant properties of gypsum compounds with plastic cable waste added in order to determine the suitability of their use as an alternative to combat moisture problems in buildings. In the experimental process, test samples were made and subjected to capillary water absorption, water vapour permeability, wet chamber, water-stove cycle and total water absorption tests, and their porosimetry was also studied using the mercury porosimetry test. The results showed a significant decrease in water absorption and retention capacity. This is due in part to the reduced pore volume of the compounds that is achieved without affecting the hygrothermal properties of the gypsum products and keeping their mechanical properties above the minimum values indicated in the regulations. Thus, the material studied is a good alternative to the gypsums currently available on the market to be applied in the areas of buildings most exposed to water and it contributes to reduce environmental impacts.
\end{abstract}

\section{Introduction}

The existence of moisture in buildings promotes the onset of various pathologies that affect indoor air quality, thermal comfort and energy consumption, as well as the durability of materials and even the health of occupants [1,2]. Moisture does not have a single cause, but 'has different origins and forms of appearance' [3]. For example, depending on the origin of the water, different kinds of moisture can be generated:

- Water from building works causes damp during the construction process.

* Corresponding author at: Universidad Politécnica de Madrid, Avda. Juan de Herrera, 6, 28040 Madrid, Spain.

E-mail address: alejandra.vidales@upm.es (A. Vidales-Barriguete).
- Water from the ground produces rising damp.

- Water from the atmosphere generates infiltration damp.

- Waste water causes moisture condensation from the indoor atmosphere.

- Water from an accident generates accidental moisture.

Among the solutions to the problem, the use of materials with waterproof properties is a passive method for moderating moisture in closed environments without the need for energy consumption [2]. In the case of gypsum - one of the most common and traditional materials used in building -, its "avidity for water" and the negative effects that this causes are well known. Studies by Luis de Villanueva and Alfonso García have shown that 'gypsum resistance is halved when its moisture content reaches 1\%. This is due to the recrystallisation that occurs on its interface, although this is recuperated when it dries [4]. Conversely, gypsum is considered 
to be a great natural hygrothermal regulator by balancing the moisture in rooms, absorbing excess moisture and returning it when the environment is drier, a quality that is required in our buildings under the Technical Building Code's Basic Health and Energy Saving Documents (HS1 protection against moisture, HS3 indoor air quality, HE1 energy demand limitation) [5] and standard EN ISO 13788 [6].

Polymer materials, for their part, in addition to their lightness and durability, have the property of being almost totally impermeable [7], but are difficult to recycle [8]. Some plastic waste can, however, be recycled mechanically due to the large quantities provided by users and the fact that it can be cleaned easily. In addition, plastic waste that cannot be recycled to an acceptable quality can be used as a resource for other solutions as a raw material or in energy recovery [9]. According to PlasticsEurope, in 2016, more than 8.4 million tons of plastics were collected in Europe for recycling. Of this amount, $31.1 \%$ was recycled, $41.6 \%$ was converted into energy and the remaining $27.3 \%$ was deposited in landfills; 10 years earlier, $80 \%$ less was recycled and $43 \%$ more was deposited in landfills, so the trend is very positive [9] although environmentally acceptable values have not yet been reached.

In this context, numerous studies have been carried out on the feasibility of incorporating recycled plastics into different materials to improve their properties and, in turn, provide a solution to the accumulation of this kind of waste. Particularly notable among them have been research works that have analysed the improvement of impermeability in different compounds. These include those carried out by Zaruma, who has analysed the increased impermeability of mortars containing PET plastic aggregates [3]; Albiño, who has developed cellulose and plastic sheets with greater impermeability, strength and durability [10]; Velasquez and Reyes, who have compared the impermeability and elasticity of traditional asphalt mixtures and asphalt mixtures reinforced with plastics, the latter turning out to be more elastic than the former [11,12]; Martínez, who has created plastic and wooden boards with low porosity and great impermeability [13]; Pastor, who has made more lightweight, flexible and waterproof paving stones containing cement and plastic [14]; and Arrascue or de los Santos, who have respectively studied bricks and blocks containing lighter and more waterproof plastic material $[15,16]$. Specific studies have also been carried out on gypsum compounds with plastic added that boast improvements in, among other properties, their weight [17-22], thermal conductivity coefficient [21,23], ductility and mechanical strength [24], electromagnetic resistance [25] and bending capacity in buildings located in areas of major seismic activity [26], but no specific in-depth studies have been found on gypsum and water.

This article, therefore, seeks to address this gap by analysing how the incorporation of plastic waste improves the waterresistant properties of gypsum in its matrix and determine whether the waterproof characteristics of the plastic function well with the gypsum compound without affecting its hygrothermal properties.

\section{Materials and methods}

\subsection{Materials}

To carry out the research, the following materials were used: fast-setting European type A gypsum in accordance with UNE EN 13279-1 [27] from the company Placo, with real density according to helium pycnometry of $2.72 \mathrm{~g} / \mathrm{cm}^{3}$; water from the Isabel II Canal in Madrid with the technical characteristics established by standard UNE EN 13279-2 [28]. The plastic cable waste (referred to as PW in this work) consisted of a diverse mixture of thermoset and thermoplastic polymers. The PW is laid out as it is obtained from Lyrsa Âlava recycling plant (Spain) after the process to which the disused cables are submitted for the recovery of the metal of the conductive thread. At the end of this process, the metal obtained is in the form of powder, ready for melting and thus, brought back into the market again; The resulting PW, on the other hand, is in the form of a particle pellet smaller than $3 \mathrm{~mm}$ (Fig. 1). These particles were collected at the recycling plant and introduced directly into the plaster without any pretreatment. Its real density according to helium pycnometry was of $1.35 \mathrm{~g} / \mathrm{cm}^{3}$ [8].

\subsection{Preparation of test samples}

To make the mixtures, the guidelines of standard UNE EN 13279-2 were followed [28]. Before adding water, the gypsum and polymer waste were dry mixed for a few seconds to prevent the waste from floating to the top. $50-60-70 \%$ of PW waste was incorporated into the gypsum mass (dosing in Table 1) with a water/gypsum mass ratio of 0.8 . The sample that contained no waste was the reference sample. Once the test samples had been demoulded, they were stored in a laboratory atmosphere for seven days at a temperature of $23 \pm 2{ }^{\circ} \mathrm{C}$ and relative humidity of $35 \pm 5 \%$ (Fig. 2). All of the tests were performed on the test samples after this time.

Six test sample series were made, according to Table 2 , of different dimensions depending on the test to be carried out:
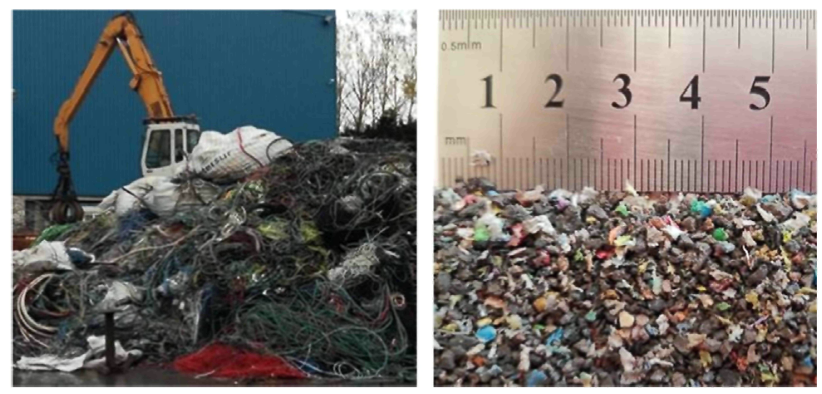

Fig. 1. (Left) Cables in the recycling plant. (Right) Plastic waste obtained after separation of the metal wire. Source: Lyrsa Álava (Spain).

Table 1

Composition of compounds.

\begin{tabular}{llll}
\hline Name & Plaster $(w t \%)$ & Water $(w t \%)^{*}$ & PW $(w t \%)^{*}$ \\
\hline E0.8 & 100 & 80 & 0 \\
E0.8-50PW & 100 & 80 & 50 \\
E0.8-60PW & 100 & 80 & 60 \\
E0.8-70PW & 100 & 80 & 70
\end{tabular}

*Calculated on the gypsum mass.

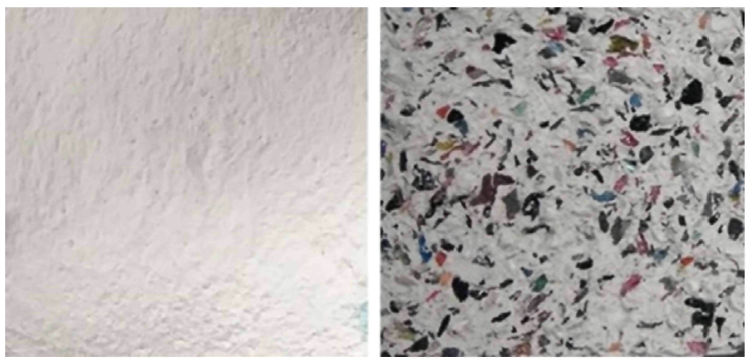

Fig. 2. Reference compound E0.8 (left) and compound incorporating PW (right). 
Table 2

Denomination of test samples, dimensions and test carried out.

\begin{tabular}{|c|c|c|c|c|}
\hline Series of prismatic samples & Name & $\mathrm{PW}(\mathrm{wt} \%)^{*}$ & Dimensions $^{* *}$ & Test carried out \\
\hline Series I & $\begin{array}{l}\text { E0.8 } \\
\text { E0.8-50PW } \\
\text { E0.8-60PW } \\
\text { E0.8-70PW }\end{array}$ & $\begin{array}{l}0 \% \\
50 \% \\
60 \% \\
70 \%\end{array}$ & $\begin{array}{l}4 \times 4 \times 16 \mathrm{~cm}^{3} \\
4 \times 4 \times 16 \mathrm{~cm}^{3} \\
4 \times 4 \times 16 \mathrm{~cm}^{3} \\
4 \times 4 \times 16 \mathrm{~cm}^{3}\end{array}$ & $\begin{array}{l}\text { Shore } C \text { hardness } \\
\text { Bending } \\
\text { Compression }\end{array}$ \\
\hline Series II & $\begin{array}{l}\text { E0.8 } \\
\text { E0.8-50PW } \\
\text { E0.8-60PW } \\
\text { E0.8-70PW }\end{array}$ & $\begin{array}{l}0 \% \\
50 \% \\
60 \% \\
70 \%\end{array}$ & $\begin{array}{l}4 \times 4 \times 16 \mathrm{~cm}^{3} \\
4 \times 4 \times 16 \mathrm{~cm}^{3} \\
4 \times 4 \times 16 \mathrm{~cm}^{3} \\
4 \times 4 \times 16 \mathrm{~cm}^{3}\end{array}$ & Capillary water absorption \\
\hline Series III & $\begin{array}{l}\text { E0.8 } \\
\text { E0.8-50PW } \\
\text { E0.8-60PW } \\
\text { E0.8-70PW }\end{array}$ & $\begin{array}{l}0 \% \\
50 \% \\
60 \% \\
70 \%\end{array}$ & $\begin{array}{l}\emptyset 16.5 \mathrm{~cm} \mathrm{~h}: 1.5 \mathrm{~cm} \\
\emptyset 16.5 \mathrm{~cm} \mathrm{~h}: 1.5 \mathrm{~cm} \\
\emptyset 16.5 \mathrm{~cm} \mathrm{~h}: 1.5 \mathrm{~cm} \\
\emptyset 16.5 \mathrm{~cm} \mathrm{~h}: 1.5 \mathrm{~cm}\end{array}$ & Water vapour permeability \\
\hline Series IV & $\begin{array}{l}\text { E0.8 } \\
\text { E0.8-50PW } \\
\text { E0.8-60PW } \\
\text { E0.8-70PW }\end{array}$ & $\begin{array}{l}0 \% \\
50 \% \\
60 \% \\
70 \%\end{array}$ & $\begin{array}{l}4 \times 4 \times 16 \mathrm{~cm}^{3} \\
4 \times 4 \times 16 \mathrm{~cm}^{3} \\
4 \times 4 \times 16 \mathrm{~cm}^{3} \\
4 \times 4 \times 16 \mathrm{~cm}^{3}\end{array}$ & $\begin{array}{l}\text { Wet chamber } \\
\text { Shore } C \text { hardness } \\
\text { Bending } \\
\text { Compression }\end{array}$ \\
\hline Series $\mathrm{V}$ & $\begin{array}{l}\text { E0.8 } \\
\text { E0.8-50PW } \\
\text { E0.8-60PW } \\
\text { E0.8-70PW }\end{array}$ & \begin{tabular}{l|}
$0 \%$ \\
$50 \%$ \\
$60 \%$ \\
$70 \%$
\end{tabular} & $\begin{array}{l}4 \times 4 \times 16 \mathrm{~cm}^{3} \\
4 \times 4 \times 16 \mathrm{~cm}^{3} \\
4 \times 4 \times 16 \mathrm{~cm}^{3} \\
4 \times 4 \times 16 \mathrm{~cm}^{3}\end{array}$ & $\begin{array}{l}\text { Water-stove cycle } \\
\text { Shore } C \text { hardness } \\
\text { Bending } \\
\text { Compression }\end{array}$ \\
\hline Series VI & $\begin{array}{l}\text { E0.8 } \\
\text { E0.8-50PW } \\
\text { E0.8-60PW } \\
\text { E0.8-70PW }\end{array}$ & $\begin{array}{l}0 \% \\
50 \% \\
60 \% \\
70 \%\end{array}$ & $\begin{array}{l}30 \times 30 \times 1.5 \mathrm{~cm}^{3} \\
30 \times 30 \times 1.5 \mathrm{~cm}^{3} \\
30 \times 30 \times 1.5 \mathrm{~cm}^{3} \\
30 \times 30 \times 1.5 \mathrm{~cm}^{3}\end{array}$ & Total water absorption \\
\hline Series VII & $\begin{array}{l}\text { E0.8 } \\
\text { E0.8-50PW } \\
\text { E0.8-60PW } \\
\text { E0.8-70PW }\end{array}$ & $\begin{array}{l}0 \% \\
50 \% \\
60 \% \\
70 \%\end{array}$ & $\begin{array}{l}\emptyset 1 \mathrm{~cm} \mathrm{~h}: 1 \mathrm{~cm} \\
\emptyset 1 \mathrm{~cm} \mathrm{~h}: 1 \mathrm{~cm} \\
\emptyset 1 \mathrm{~cm} \mathrm{~h}: 1 \mathrm{~cm} \\
\emptyset 1 \mathrm{~cm} \mathrm{~h}: 1 \mathrm{~cm}\end{array}$ & Mercury porosimetry \\
\hline
\end{tabular}

Calculated on the gypsum mass.

" $ø$ : diameter; h: height of the test sample.

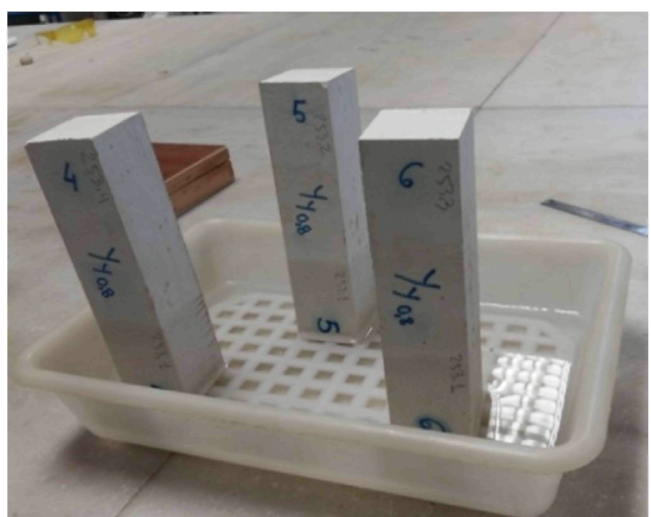

Fig. 3. Prismatic test samples (Series III) during the capillary water absorption test.

\subsection{Experimental plan}

The experimental plan was based on the following tests: capillary water absorption, water vapour permeability, wet chamber, water-stove cycle and total water absorption, together with a porosimetry test to relate the correspondence of avidity for water and the pores of the compound.

\subsubsection{Capillary water absorption}

This was carried out to analyse the rate at which water rises by capillarity through the test sample, based on standard RILEM TC 25-PEM [29]. Once the prismatic test samples were dried, they were placed in a vertical position in a container with $10 \mathrm{~mm} \pm 1 \mathrm{~mm}$ of water. Over a period of $10 \mathrm{~min}$, the water level reached on each side was measured every minute (Fig. 3) and the final result was expressed in millimetres per minute.

\subsubsection{Water vapour permeability}

This was used to determine the water vapour transmission properties of the compounds, based on standard UNE EN ISO 12572 [30]. Circular test samples $15 \mathrm{~mm} \pm 5 \mathrm{~mm}$ thick were made and stored for 7 days at a temperature of $23 \pm 5^{\circ} \mathrm{C}$ and relative humidity of $50 \pm 5 \%$ (Fig. 4).

Subsequently, to ensure a relative humidity of $94 \%$, a saturated aqueous solution of potassium nitrate dissolved in water was made, deposited in the test cup and on each circular test sample and sealed with silicone adhesive. On a weekly basis for 8 weeks, the weights were recorded to finally determine permeability by means of the expression:

$P=P R \cdot e$

P: water vapour permeability $[\mathrm{g} /(\mathrm{m} \cdot \mathrm{h} \cdot \mathrm{mmHg})]$

e: thickness of the test sample $(\mathrm{m})$

PR: water vapour permeance $\left[\mathrm{g} /\left(\mathrm{m}^{2} \cdot \mathrm{h} \cdot \mathrm{mmHg}\right)\right]$, which is given by the expression:

$P R=W V T / \Delta p$

$\Delta \mathrm{p}$ : obtained from the expression

$\Delta p=S(R 1-R 2)$

S: water vapour saturation pressure at the test temperature $(\mathrm{mmHg})$. Average temperature $21^{\circ} \mathrm{C}$, saturation pressure $18,663 \mathrm{mmHg}$.

R1: relative humidity \%, on the side with the highest vapour pressure (expressed as a fraction). With potassium nitrate, the relative humidity reached was $94 \%$. 

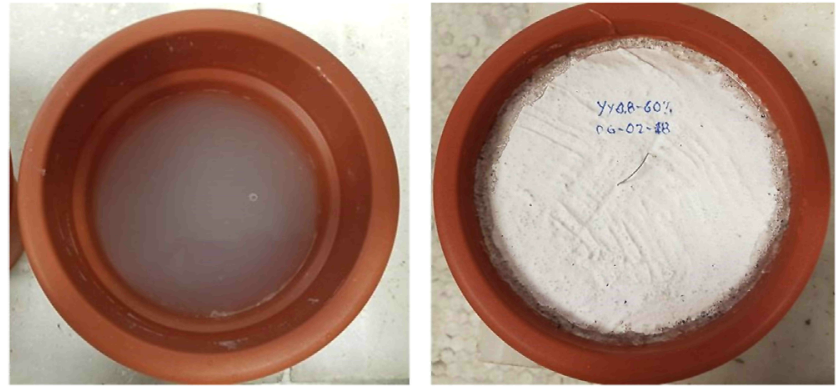

Fig. 4. Aqueous solution for the water vapour permeability test (left); sealing of the test cup containing the Series III test sample (right).

R2: relative humidity \%, on the side with the lowest vapour pressure (expressed as a fraction). The environmental relative humidity was $50 \%$.

WVT: water vapour transmission rate $\left[\mathrm{g} /\left(\mathrm{m}^{2} \cdot \mathrm{h}\right)\right]$, which is given by the expression:

$W V T=\Delta m /(t \cdot A)$

$\Delta \mathrm{m}$ : mass change $(\mathrm{g})$ at time $\mathrm{t}$

$\mathrm{t}$ : length of time between readings (h). Final permeability was calculated on the basis of a time between readings of $1344 \mathrm{~h}$. A: sample test area in $\mathrm{m}^{2}\left(0.02138246 \mathrm{~m}^{2}\right)$

And, finally, water vapour resistance is given by the expression:

$R=1 / P R$

$\mathrm{R}$ : water vapour resistance $\left[\left(\mathrm{m}^{2} \cdot \mathrm{h} \cdot \mathrm{mmHg} / \mathrm{g}\right)\right]$

\subsubsection{Wet chamber}

This was performed to analyse the behaviour of the compounds when subjected to constant moisture, using the non-standardised test designed by del Río Merino in his doctoral thesis [17]. Over five days, prismatic test samples were placed in a wet chamber at a temperature of $21^{\circ} \mathrm{C}$ and a relative humidity of $72 \%$. Each compound's weight increase was noted, they were left in a laboratory atmosphere for 7 days and their Shore $C$ hardness and bending and compression stiffness were checked to compare them with samples that had not been tested with water [8].

\subsubsection{Water-stove cycles}

This determined the ability of the compounds to dry after being completely submerged. This test was carried out using the nonstandardised procedure used by del Río Merino in his doctoral the- sis [17]. Prismatic test samples were placed in a container and completely covered with water for 2 days (Fig. 5). They were removed, weighed and placed in a stove for another 2 days at $40 \pm 5{ }^{\circ} \mathrm{C}$. This process was carried out twice and, as in the wet chamber test, their Shore $C$ hardness and bending and compression stiffness were verified to compare them with test samples that had not been tested with water [8].

\subsubsection{Total water absorption}

To determine the total water absorption capacity of the compounds, the test defined in UNE-EN 520 was used [31]. In this case, the test samples had dimensions of $300 \pm 1.5 \mathrm{~mm} \times 300 \pm 1.5 \mathrm{~mm}$ and a thickness of $15 \mathrm{~mm}$ (Fig. 6). Once weighed, they were fully submerged horizontally in water for $2 \mathrm{~h} \pm 2 \mathrm{~min}$ and covered with

25-35 $\mathrm{mm}$ of water, while remaining raised up off the bottom of the container. They were removed from the water, dried using blotting paper and reweighed.

\subsubsection{Mercury porosimetry}

This test was carried out to determine compound pore volume and distribution and attempt to relate the results to water contact behaviour. Cylindrical test samples measuring $10 \mathrm{~mm}$ in diameter and $10 \mathrm{~mm}$ in height were prepared (Fig. 7). and tested on the Autopore IV 9500 instrument manufactured by Micromeritics Instrument Corporation. Through the intrusion of mercury into the porous structure of the samples using controlled pressure, information was obtained on the volume, size, surface area and average diameter of the pores, in addition to the bulk and skeletal density.

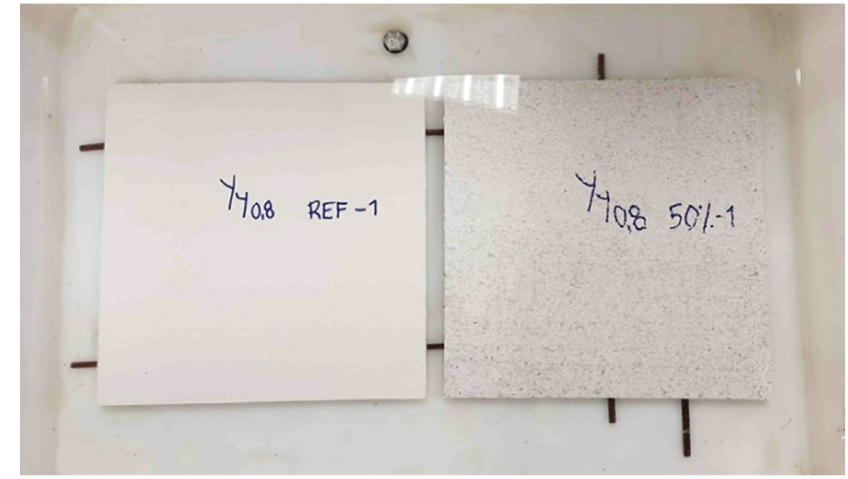

Fig. 6. Panel test samples (Series VI) submerged during the total water absorption test.
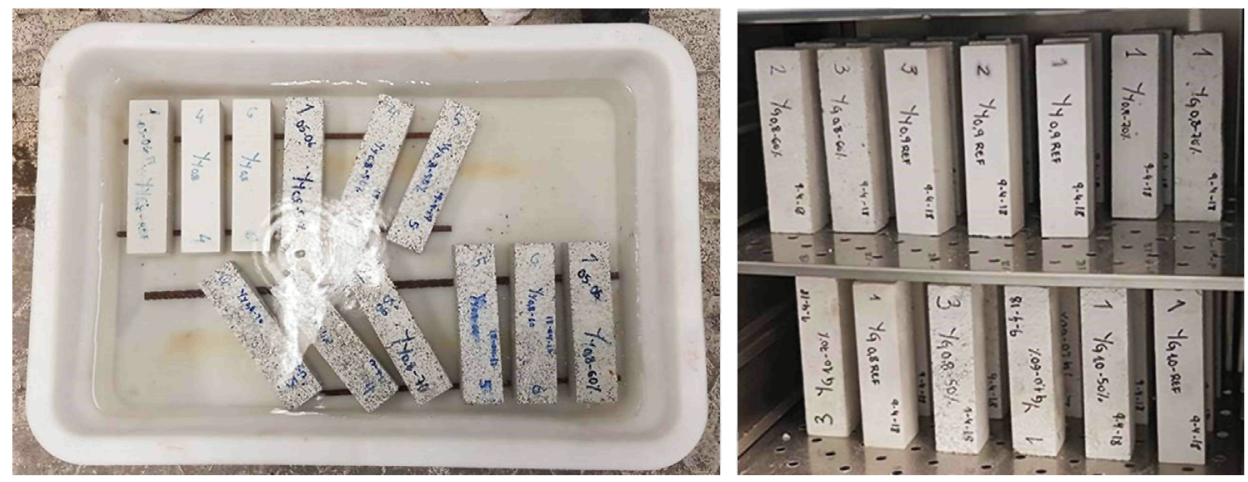

Fig. 5. Prismatic test samples (Series V) submerged (left), prismatic test samples in the stove (right) during the water-stove cycle. 


\section{Results and discussion}

Firstly, during the preparation of the Series II test samples, we recorded their wet weight (when demoulding the test samples) and dry weight (after 7 days at an ambient temperature of $23 \pm 2{ }^{\circ} \mathrm{C}$ and relative humidity of $35 \pm 5 \%$, they spent $24 \mathrm{~h}$ in a stove at a temperature of $40 \pm 2{ }^{\circ} \mathrm{C}$ until constant mass and were cooled in a dryer down to laboratory ambient temperature) to determine their water retention capacity during preparation (Table 3):

The water retention capacity of the mixtures during their preparation, in relation to the reference sample, decreased as PW was incorporated into them by $27.10-25.78-24.96 \%$ respectively with $50-60-70 \%$. This decrease in water retention capacity can be explained by the addition of PW, which acts as a barrier, making it difficult for water molecules to enter the mixture, and is corroborated by other research into cement matrix and PET polymer waste (polyethylene terephthalate) [32]. The compound with the lowest water retention capacity was E0.8-70PW (24.96\%) and the one with the highest was E0.8-50PW (27.10\%), which was still an improvement on the reference sample which retained $35.03 \%$ of water.

\subsection{Capillary water absorption}

The average capillary water absorption result is shown in Fig. 8, together with the weights obtained before and after the test for each of the test samples:

The weight increase of the compounds through the absorption of water by capillarity, after $10 \mathrm{~min}$ of the test, were 7.31-5.91$6.26 \%$ for $50-60-70 \% \mathrm{PW}$, respectively, while for the reference sample the weight increase reached $17.03 \%$. That is, the weight increase of the compounds with PW was more than 50\% lower than the weight increase of the reference.

It is observed that water uptake reduced by $42.59-57.41-62.9$ $6 \%$ respectively in the $50-60-70 \% \mathrm{PW}$ compounds compared to the reference compound, exceeding the $40 \%$ reduction in capillary water absorption achieved in other studies carried out with gypsum matrix and polyurethane polymer waste [33]. The compound with the lowest capillary water absorption capacity was E0.8$70 \mathrm{PW}(2.0 \mathrm{~mm} / \mathrm{min})$ and the one with the highest was E0.850PW (3.1 $\mathrm{mm} / \mathrm{min})$.

\subsection{Water vapour permeability}

The study was carried out over 8 weeks and the results are shown in Fig. 9. In addition, Table 4 shows the values obtained

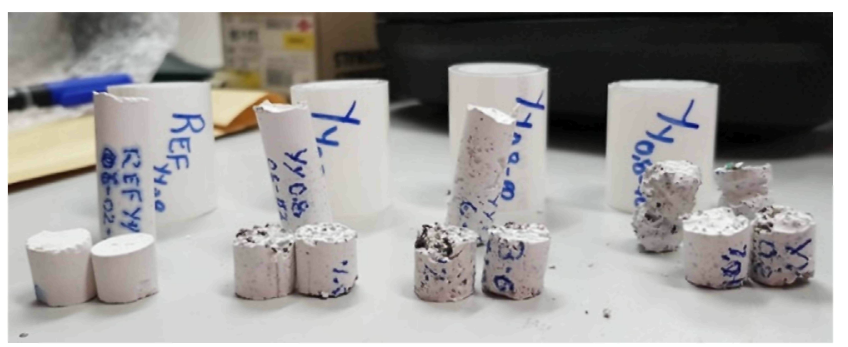

Fig. 7. Samples prepared for the mercury porosimetry test (Series VII).

Table 3

Compound wet and dry weights (Series II) and water retention capacity.

\begin{tabular}{llll}
\hline Denomination & Wet weight $(\mathrm{g})$ & Dry weight $(\mathrm{g})$ & Water retention $(\%)$ \\
\hline E0.8 & 389.7 & 253.2 & 35.03 \\
E0.8-50PW & 354.2 & 258.2 & 27.10 \\
E0.8-60PW & 352.6 & 261.7 & 25.78 \\
E0.8-70PW & 346.2 & 259.8 & 24.96 \\
\hline
\end{tabular}

for permeability (P), transmission (WVT), permeance (PR) and water vapour resistance $(R)$ at the end of the 8 weeks.

The behaviour of the different compounds, including the reference, was very similar: in the second week, permeability increased compared to the first week and, from the third, the permeability values experienced a slight decrease as the weeks passed. At the end, all of the compounds and the reference sample had very similar water vapour permeability values, all lower than the first week: the reference sample, $17.53 \%$ less; the $50 \% \mathrm{PW}$ and $60 \% \mathrm{PW}$, $18.42 \%$ less; and the $70 \% \mathrm{PW}$; $16.48 \%$ less.

At the end of the 8 weeks, the $50 \% \mathrm{PW}-60 \% \mathrm{PW}-70 \% \mathrm{PW}$ compounds had reduced transmission, permeance and permeability values compared to the reference sample by $27.61-28.22-41.72 \%$ respectively. Conversely, in an inverse relationship, their resistance to water vapour increased by $38.84-39.37-72.71 \%$ compared to the compound without PW. The compound with the lowest permeability and, therefore, with the highest resistance to water vapour was E0.8-70PW $(0.0095[\mathrm{~g} /(\mathrm{m} \cdot \mathrm{h} \cdot \mathrm{mmHg})]$ and 1.7986 $\left[\left(\mathrm{h} \cdot \mathrm{m}^{2} \cdot \mathrm{mmHg} / \mathrm{g}\right)\right]$; the compound with the highest permeability and, therefore, the lowest resistance to water vapour was E0.850PW $\left(0.0118[\mathrm{~g} /(\mathrm{m} \cdot \mathrm{h} \cdot \mathrm{mmHg})]\right.$ and $1.4459\left[\left(\mathrm{~h} \cdot \mathrm{m}^{2} \cdot \mathrm{mmHg} / \mathrm{g}\right)\right]$. Obviously, the lower the amount of plastic waste, the lower the vapour barrier.

\subsection{Wet chamber}

Table 5 shows the weight increase values obtained during the wet chamber test. Shore $C$ hardness and bending and compression stiffness are shown in Fig. 15 respectively.

After this process of exposure to continuous moisture, the water retention capacity was $25.38 \%$ and $46.54 \%$ lower in the compounds with $50 \% \mathrm{PW}$ and $60 \% \mathrm{PW}$ compared to the reference compound, but practically the same in the 70\% PW compound $(+0.77 \%)$. The compound with the lowest water retention capacity with continuous moisture was E0.8-60PW $(+1.39 \%)$ and the one with the highest was E0.8-70PW (+2.62\%).

\subsection{Water-stove cycles}

Table 6 shows the data obtained in the test of the two waterstove cycles. Shore $\mathrm{C}$ hardness and bending and compression stiffness are shown in Fig. 15 respectively.

After each of the water-stove cycles, the water retention capacity of the compounds was similar, around $35 \%$ in the mixtures with PW and $43 \%$ in the reference mixture. The deterioration suffered by the test samples is shown in Fig. 10. The compounds with 50-60$70 \% \mathrm{PW}$ had decreased water retention by $18.74-22.78-24.99 \%$ compared to the compound without PW. The compound with the lowest water retention capacity after 2 water-stove cycles was E0.8-70PW $(+32.86 \%)$ and the one with the highest was E0.8$50 \mathrm{PW}(+35.60 \%)$. In all cases, the results of the compounds after the test were very similar.

The loss of gypsum material shows the load of the plastic waste, which, it can be observed, is evenly distributed.

\subsection{Total water absorption}

The data obtained in the total water absorption test of the panels is shown in Fig. 11.

Water absorption capacity decreased as PW was incorporated into the mixture, specifically by $32.64-29.79-29.68 \%$ respectively in the compounds with 50\%PW-60\%PW-70\% PW. In addition, with regard to the reference sample, the values obtained were 27.26 $33.61-33.85 \%$ lower. The compound with the lowest total water absorption was E0.8-70PW $(+29.68 \%)$ and the one with the highest was E0.8-50PW $(+32.64 \%)$. 


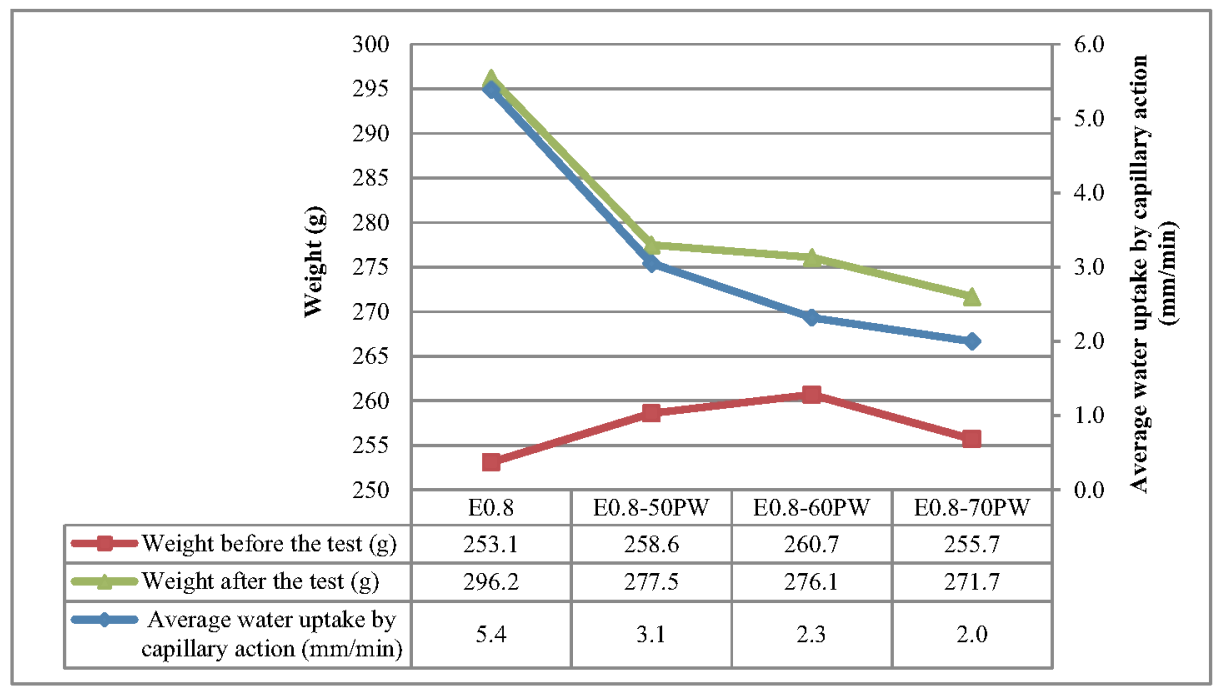

Fig. 8. Weights of the Series II compounds before and after the capillary water absorption test and average water uptake by capillarity.

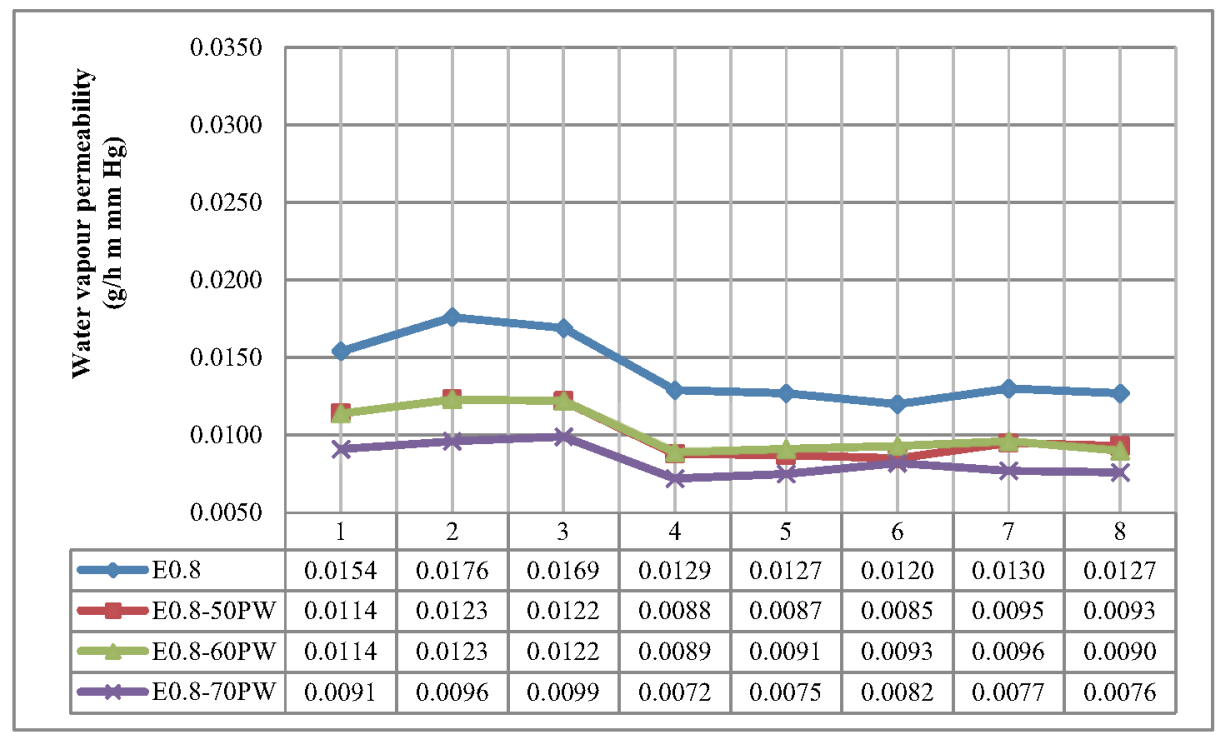

Fig. 9. Water vapour permeability (Series III) every week for 8 weeks.

Table 4

Final result of water vapour transmission, permeance, permeability and resistance (Series III) in accordance with UNE-EN ISO 12572.

\begin{tabular}{|c|c|c|c|c|}
\hline Denom. & WVT $\left(\mathrm{g} / \mathrm{h} \cdot \mathrm{m}^{2}\right)$ & $\mathrm{PR}\left(\mathrm{g} / \mathrm{h} \cdot \mathrm{m}^{2} \cdot \mathrm{mmHg}\right)$ & $\mathrm{P}(\mathrm{g} / \mathrm{h} \cdot \mathrm{m} \cdot \mathrm{mmHg})$ & $\mathrm{R}\left(\mathrm{h} \cdot \mathrm{m}^{2} \cdot \mathrm{mmHg} / \mathrm{g}\right)$ \\
\hline E0.8 & 7.8850 & 0.9602 & 0.0163 & 1.0414 \\
\hline E0.8-50PW & 5.6789 & 0.6916 & 0.0118 & 1.4459 \\
\hline E0.8-60PW & 5.6580 & 0.6890 & 0.0117 & 1.4514 \\
\hline E0.8-70PW & 4.5654 & 0.5560 & 0.0095 & 1.7986 \\
\hline
\end{tabular}

\subsection{Mercury porosimetry}

Table 5

Water retention (Series IV) in the wet chamber test.

\begin{tabular}{llll}
\hline Denom. & $\begin{array}{l}\text { Weight before the } \\
\text { test }-\mathrm{dry}(\mathrm{g})\end{array}$ & $\begin{array}{l}\text { Weight after } \\
\text { the test }- \text { wet }(\mathrm{g})\end{array}$ & $\begin{array}{l}\text { Water } \\
\text { retention (\%) }\end{array}$ \\
\hline E0.8 & 254.20 & 260.80 & $+2.60 \%$ \\
E0.8-50PW & 263.50 & 268.60 & $+1.94 \%$ \\
E0.8-60PW & 267.00 & 270.70 & $+1.39 \%$ \\
E0.8-70PW & 270.60 & 277.70 & $+2.62 \%$ \\
\hline
\end{tabular}

The experimental results for $\mathrm{Hg}$ porosimetry are presented in Table 7 and Fig. 12.

It is observed that the reference sample has the highest pore volume. The addition of plastic decreases pore volume, and the $70 \%$ compound has the smallest pore volume value.

According to these results, the reference compound is the one with the lowest bulk density (density that includes the pores), and the compounds with plastic added show higher bulk density values, the highest being that for the 70\% PW compound. 
Table 6

Water retention (Series V) after 2 water-stove cycles.

\begin{tabular}{|c|c|c|c|c|c|c|c|}
\hline Denom. & $\begin{array}{l}\text { Initial } \\
\text { weight - dry (g) }\end{array}$ & $\begin{array}{l}\text { Weight after } \\
\text { cycle } 1 \text { - wet (g) }\end{array}$ & $\begin{array}{l}\text { Water retention } \\
\text { cycle } 1(\%)\end{array}$ & $\begin{array}{l}\text { Weight after } \\
\text { cycle } 1 \text { - dry (g) }\end{array}$ & $\begin{array}{l}\Delta \text { weight compared } \\
\text { to initial weight }\end{array}$ & $\begin{array}{l}\text { Weight after } \\
\text { cycle } 2 \text { - wet (g) }\end{array}$ & $\begin{array}{l}\text { Water retention } \\
\text { cycle } 2(\%)\end{array}$ \\
\hline E0.8 & 260.90 & 371.80 & $+42.51 \%$ & 257.00 & $-1.49 \%$ & 369.60 & $+43.81 \%$ \\
\hline E0.8-50PW & 259.10 & 349.30 & $+34.81 \%$ & 257.60 & $-0.58 \%$ & 349.30 & $+35.60 \%$ \\
\hline E0.8-60PW & 259.60 & 344.05 & $+32.53 \%$ & 257.76 & $-0.71 \%$ & 344.96 & $+33.83 \%$ \\
\hline E0.8-70PW & 260.20 & 343.60 & $+32.05 \%$ & 259.00 & $-0.46 \%$ & 344.10 & $+32.86 \%$ \\
\hline
\end{tabular}

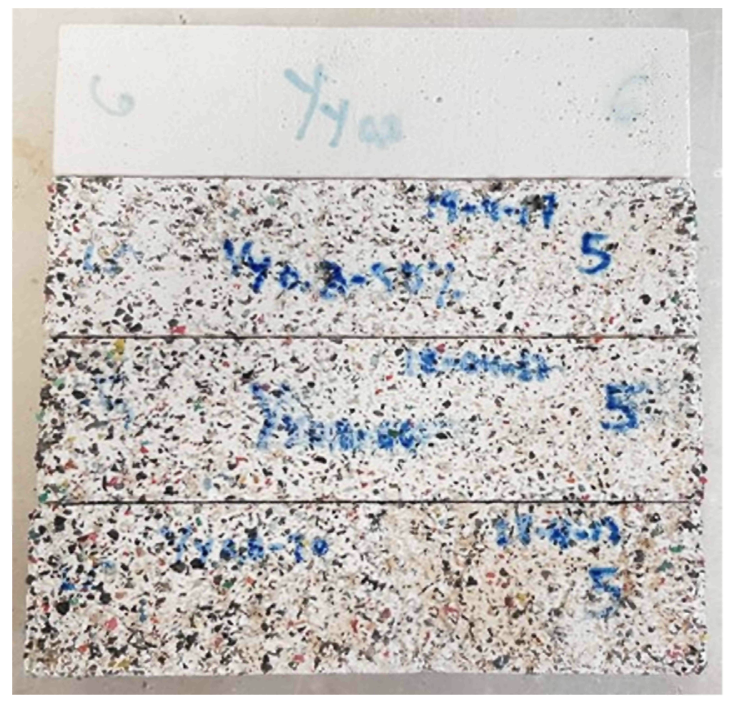

Fig. 10. Deterioration of the test samples (Series V) after 2 water-stove cycles.

The real density values (material density excluding pores) are logically higher than those of bulk density. The higher value corresponds to the reference compound, and the values decrease as the percentage of plastic in the compounds increases, with the $70 \% \mathrm{PW}$ sample being the one with the lowest real density. This correlates well with the higher real density value of the gypsum compared to the PW presented in Section 2.1, with the matrix of the compounds with plastic added being lighter the more the amount of PW it contains.

All of the compounds, both the reference sample and those containing PW, have a very similar unimodal pore size distribution. In all cases more than $96 \%$ of the pore volume corresponds to macropores with diameter larger than $50 \mathrm{~nm}$ in accordance with the IUPAC classification, whereas the mesopores, with diameter comprised between 3 and $50 \mathrm{~nm}$, accounts for less than $4 \%$ of pore vol- ume. The macropore pore volume decreases slightly as the PW content increases. In the differential pore size distribution (Fig. 14), it can be observed that all of the samples have a maximum around $1500-2500 \mathrm{~nm}$. In the samples with PW added, it is observed that for pore sizes smaller than $20 \mathrm{~nm}$ a second maximum in the pore volume is started, but, as can be seen in the accumulated distribution, this pore volume for the three samples with PW added represents a very small percentage of the pore volume, with $1.6-1.8-2.7 \%$ for the samples with $50-60-70 \%$ PW respectively. Therefore, the mesopore pore volume increases very slightly as the PW content increases.

These results show that the addition of $\mathrm{PW}$ to the gypsum matrix has the main effect of decreasing the pore volume, but this barely affects the size distribution of these pores. This result can be explained by the fact that the origin of these pores is due to the crystalline framework formed by dihydrate gypsum crystals in the form of needles and plates, which are formed due to the hydration of the hemihydrate during setting [8]. This porous network, with its distinctive pore size, is simply present in a lower proportion in the samples with the greater amount of PW added, which explains the lower pore volume.

This lower pore volume in the samples with PW added, as well as the lower mass of gypsum present in them (the higher the \% of PW, the lower the \% of gypsum) explains the lower water absorption capacity. This effect could also be attributed to the slightly minor macropore pore volume and the slightly larger mesopore pore volume as the PW content increase.

\subsection{Comparison of Shore C hardness, bending and compression}

To verify the effect of water on mechanical properties, a comparison was made between the Shore $C$ hardness and bending and compression stiffness results obtained by the Series IV and V test samples and test samples that had not been subjected to tests with water (Series I). The results are shown in Figs. 13-15.

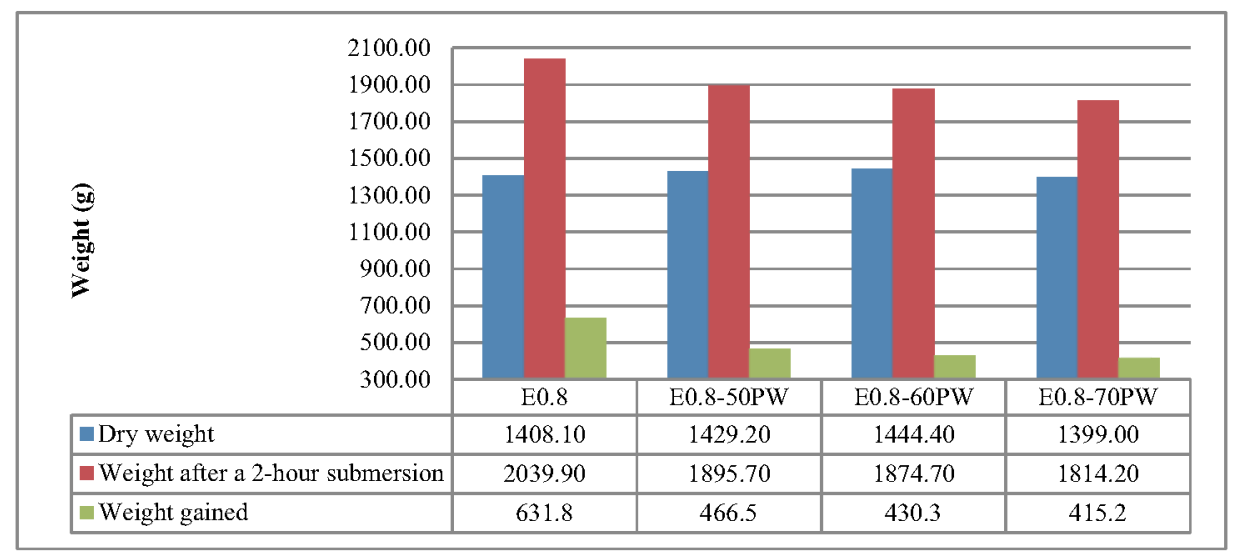

Fig. 11. Weights before and after (Series VI) the total water absorption test in accordance with standard UNE-EN 520. 
Table 7

Textural properties (Series VII) obtained from the mercury porosimetry test.

\begin{tabular}{|c|c|c|c|c|c|c|c|c|}
\hline Denom. & Pore volume $\left(\mathrm{cm}^{3} / \mathrm{g}\right)$ & $\begin{array}{l}\text { Bulk Density } \\
\left(\mathrm{g} / \mathrm{cm}^{3}\right)\end{array}$ & $\begin{array}{l}\text { Skeletal Density } \\
\left(\mathrm{g} / \mathrm{cm}^{3}\right)\end{array}$ & Porosity (\%) & $\begin{array}{l}\text { Macropore } \\
\text { Volume (\%) }\end{array}$ & $10 \% \mathrm{Vp}^{<}{ }^{(1)}(\mathrm{nm})$ & $50 \% \mathrm{Vp}^{<}<^{(1)}(\mathrm{nm})$ & $90 \% V_{p}<{ }^{(1)}(\mathrm{nm})$ \\
\hline $\mathrm{E}_{0.8}$ & 0.5419 & 1.0166 & 2.2639 & 55.09 & 99.66 & 838 & 2143 & 72,000 \\
\hline $\mathrm{E}_{0.8-50 \mathrm{PR}}$ & 0.4067 & 1.0542 & 1.8453 & 42.87 & 97.91 & 679 & 1819 & 3511 \\
\hline $\mathrm{E}_{0.8-60 \mathrm{PR}}$ & 0.4276 & 1.0235 & 1.8200 & 43.76 & 97.71 & 676 & 2000 & 3163 \\
\hline $\mathrm{E}_{0.8-7 \mathrm{OPR}}$ & 0.3447 & 1.0776 & 1.7145 & 37.14 & 96.62 & 1169 & 2290 & 3916 \\
\hline
\end{tabular}

(1) $10 \% \mathrm{Vp}<, 50 \% \mathrm{Vp}<, 90 \% \mathrm{Vp}<: 10,50$ and $90 \%$ respectively of the pore volume showed a smaller size (nm) to that presented in the corresponding columns.
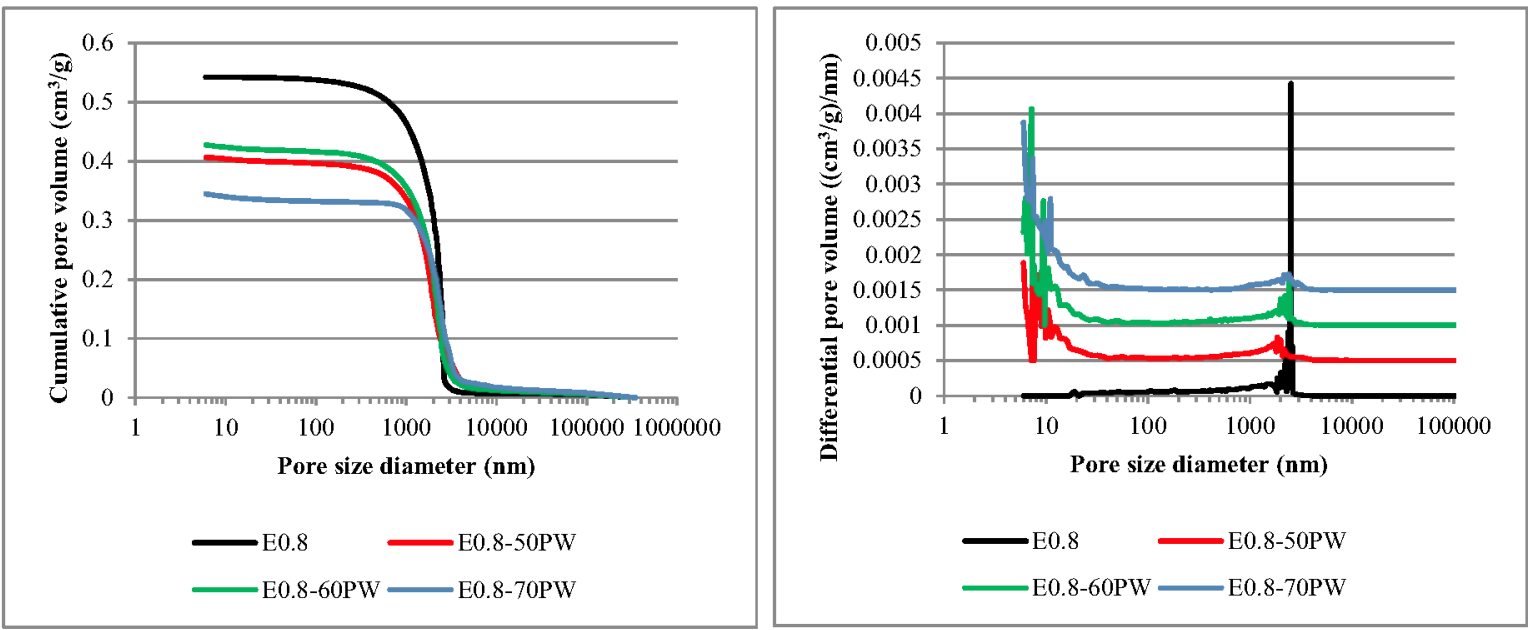

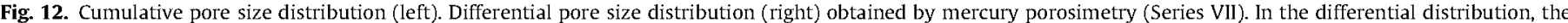
curves in the vertical axis have been moved to separate them.

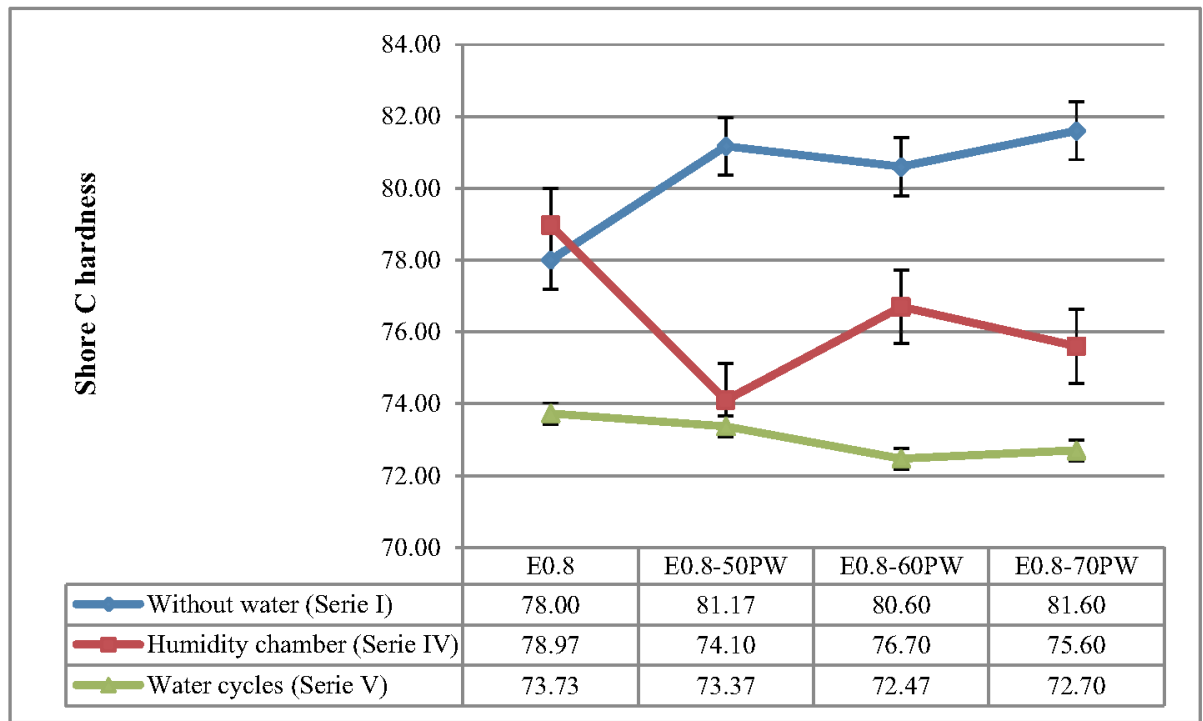

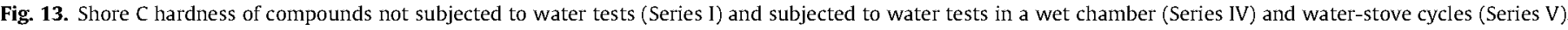

Regarding the test samples that had not been tested with water (Series I), Shore $C$ hardness decreased in all compounds tested with water between $5 \%$ and $9 \%$ in the case of continuous moisture (Series IV) and between $5 \%$ and $11 \%$ in the case of water saturation and drying cycles (Series $V$ ) due to the deterioration that the surface layer of the test samples suffered after the tests. In spite of this, all of the values remained above a Shore $C$ hardness of 70.00 (no minimum value is specified in the regulations for building gypsums).

With continuous moisture (Series IV) and comparing it to Series I, bending stiffness decreases approximately equally, by $12 \%$, in the reference test sample compared to the test samples of the compounds with PW. With the water saturation and drying cycles, however, the reference test sample was less affected; its bending stiffness decreased by approximately $15 \%$, while the bending stiffness of the test samples with PW reduced by up to $40 \%$. It should be noted that all values still remained above the $1 \mathrm{~N} / \mathrm{mm}^{2}$ minimum indicated in UNE EN 13279-2 [28].

Compression stiffness with continuous moisture (Series IV), compared to Series I, decreased by only $3.48 \%$ in the reference test sample and, in contrast, between $24 \%$ and $29 \%$ in the compound test samples. With the water saturation and drying cycles (Series 


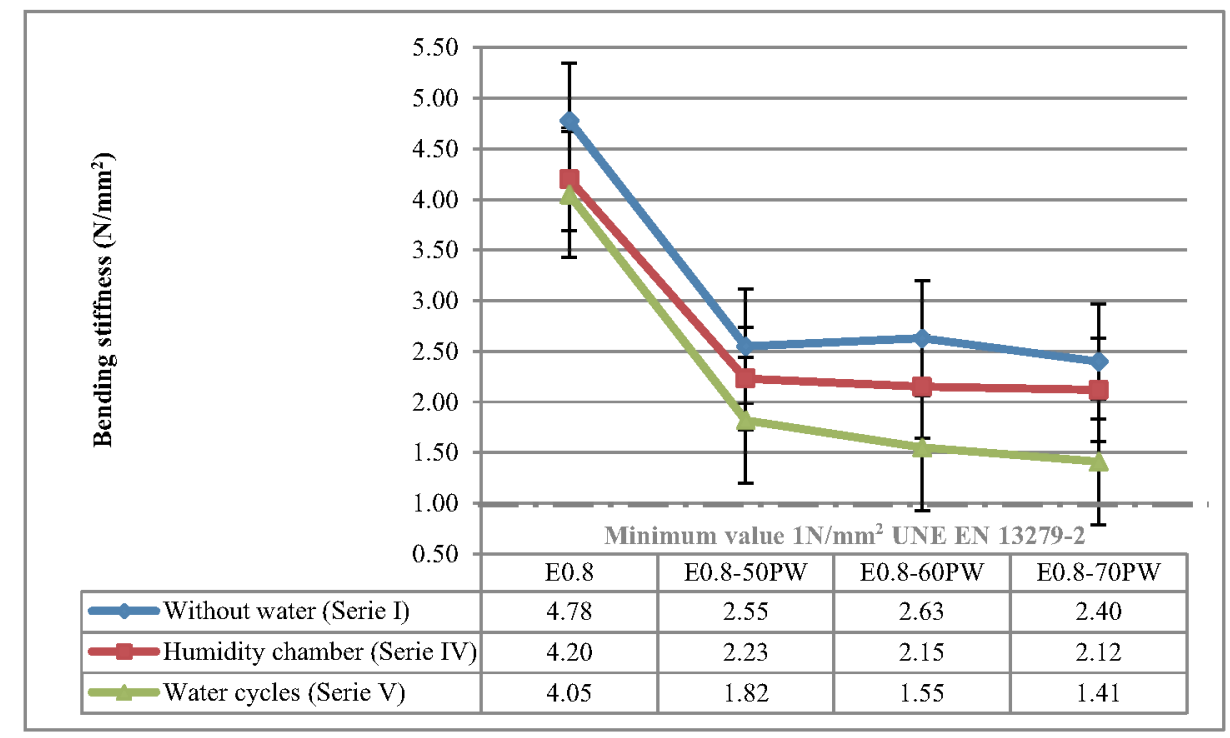

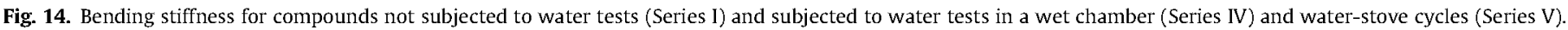

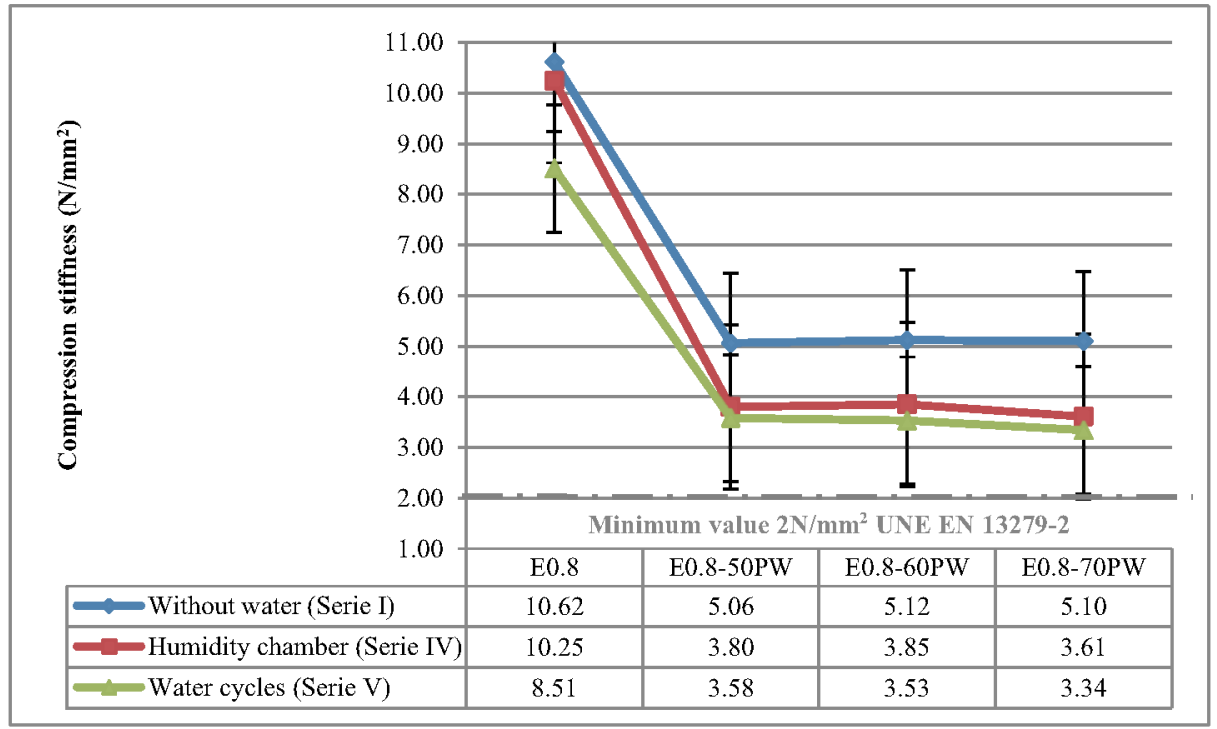

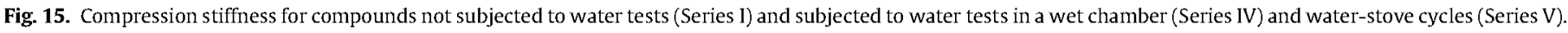

$V)$, the compression stiffness of the reference test sample decreased by approximately $20 \%$, while that of the compound test samples was reduced by between $29 \%$ and $34.5 \%$. In this case, all of the values were also above the $2 \mathrm{~N} / \mathrm{mm}^{2}$ minimum indicated in UNE EN 13279-2 [28].

\section{Conclusions}

With the use of plastic cable waste as aggregates in gypsum matrices, compounds with a water absorption capacity significantly lower than gypsum without plastic cable waste were achieved, while retaining, in accordance with the air permeability test, the capacity to regulate relative humidity in the indoor rooms of buildings characteristic of gypsum, as well as keeping their mechanical properties above the minimum values indicated in the regulations. This fact was more notable in the compounds with $50 \%$ and $60 \%$ of PW, since their behaviour, in all of the tests, was more constant.

Gypsum with PW can therefore be considered a good plaster to apply in areas of buildings with greater exposure to water, such as basement floors or ground floors on screeds, walls with recesses and even exterior walls protected by corrugated roofs, porches, etc. This would facilitate the breathability of the walls and help avoid pathologies resulting from surface and interstitial condensation.

Using the proposed material, and taking into account that plastering a $1 \mathrm{~m}^{2}$ wall requires approximately $5 \mathrm{~kg}$ of gypsum and $4 \mathrm{~L}$ of water, it could be possible to achieve a raw material saving of $1.25-1.50 \mathrm{~kg}$ of gypsum and $1.0-1.20 \mathrm{~L}$ of water per $1 \mathrm{~m}^{2}$. This would represent a decrease in the use of these natural resources by between 25 and 30\% which, in addition to the reduction in the amount of existing plastic waste, would contribute to minimising environmental impact through building materials.

\section{Declaration of Competing Interest}

The authors declare that they have no known competing financial interests or personal relationships that could have appeared to influence the work reported in this paper. 


\section{References}

[1] P. Martínez, P. Sarmiento, W. Urquieta, Evaluación de la humedad por condensación de viviendas sociales, INVI 20 (2005) 154-165.

[2] C.C. Sardiña, Caracterización y Modelización de las Propiedades de los Materiales Frente a la Humedad Interior para la Optimización del Confort Térmico y el Consumo de Energía en los Edificios, Universidade da Coruña (España), 2011. PhD.

[3] L.A. Zaruma Uzhca, Mortero Impermeable a Base de Plástico Reciclado PET Para Revestimientos de Edificaciones de la Ciudad de Zamora PhD, Universidad de Cuenca (Ecuador), 2018.

[4] L. de Villanueva Domínguez, A. García Santos, Manual del yeso, CIE Inversiones Editoriales-DOSSAT 2000, Madrid (España), 2001.

[5] CTE, Código Técnico de la Edificación, BOE Núm. 74. (2006) 11816-11831.

[6] EN ISO 13788:2016 Características higrotérmicas de los elementos y componentes de edificación. Temperatura superficial interior para evitar la humedad superficial crítica y la condensación intersticial. Métodos de călculo, (2016).

[7] L.C. Huerta, Estudio del envejecimiento climático en plàsticos agrarios mediante difracción de rayos X, Universidad Politécnica de Madrid (España), 2017. doi:oai:oa.upm.es:47937.

[8] A. Vidales Barriguete, M. del Río Merino, E. Atanes Sánchez, C. Piña Ramírez, C. Viñas Arrebola, Analysis of the feasibility of the use of CDW as a lowenvironmental-impact aggregate in conglomerates, Constr. Build. Mater. 178 (2018) 83-91, https://doi.o1g/10.1016/j-conbuildmat.2018.05.011.

[9] PlasticsEurope, An analysis of European plastics production, demand and waste data, (2018). https://www.plasticseurope.org/es/resources/ publications/1240-plasticos-situacion-en-2018 (accessed May 5, 2019).

[10] F. Albiño Velasco, D. Mora Zurita, D. Mosguidt Ramos, G. Sobenis Hinojosa, C. Velasco Sânchez, L. Arellano Barragán, Elaboraciôn de planchas celuplásticas a través o del reciclaje de celulosa residual y tereftalato de polietileno (PET), Cumbres. Rev. Científica 1 (2015) 55-58.

[11] D.F. Silvestre Velasquez, Comparación Técnica y Económica entre las Mezclas Asfâlticas Tradicionales y Reforzadas con Plástico Reciclado en la Ciudad de Lima Phd, Universidad César Vallejo, Perú, 2017.

[12] F.A. Reyes Lizcano, Mezclas asfálticas modificadas con un elastómero (caucho) y un plastómero (tiras de bolsas de leche con asfalto $80-100$ ), Infraestruct. Vial. 9 (2012) 25-34.

[13] Y. Martínez-López, M. García-Gonzalez, R.R. Fernández-Concepción, D. Álvarez-Lazo, E. Martínez-Rodríguez, Proceso de transformación de la materia prima para tableros de madera plástica, Ing. Ind. 38 (2017) 235-246.

[14] A. Pastor Castillo, J.P. Salazar Oliva, R. Seminario Regalado, J.C. Zapata Valladolid, Diseño de Planta Productora de Adoquines a Base de Cemento y Plástico Reciclado, Universidad de Piura, Perú, 2015.

[15] E.J. Arrascue Bazân, M.E. Cano Herrera, Utilización de Materiales Plásticos de Reciclaje Como Adición en la Fabricación de ladrillos Vibrocompactados de Cemento PhD, Universidad Nacional del Santa, Perú, 2017.

[16] E. García De Los Santos, M. Martínez Mateo, A. Nina Pérez, A. Mejía Suero, A. Olivo Nuñez, B. Morantín Ventura, F. Ortiz, I. Escorbores, I. Roberto Féliz, Estudio de factibilidad bloques de hormigón con agregado de residuo plástico ABS, Elev. LACCEI Lat. Am. Caribb. Conf. Eng. Technol. (2013) 1-10.

[17] M. del Río Merino, Elaboración y aplicaciones constructivas de paneles prefabricados de escayola aligerada y reforzada con fibras de vidrio E y otros aditivos, PhD, Universidad Politêcnica de Madrid (España), 1999. doi:oai:oa. upm.es:612.
[18] F.J. González Madariaga, J. Lloveras Macia, Mezclas de residuos de poliestireno expandido (EPS) conglomerados con yeso o escayola para su uso en la construcción, Inf. La Constr. 60 (2008) 35-43, https://doi.org/10.3989/ic.2008. v60.1509.589.

[19] A. Jiménez Rivero, A. de Guzmán Báez, J. García Navarro, M. González Cortina, Nuevos materiales de base yeso con incorporación de residuos de caucho: caracterización físico-mecánica., Actas IX Jornadas Iberoam, Mater. Constr. (2011) 1-13.

[20] P. Villoria Sáez, M. del Río Merino, A. San-Antonio González, Material de construcción ligero fabricado con yeso y residuo de poliestireno extruido, Proc. II Int. Congr. Sustain. Constr. Eco-Efficient Solut. Sev. 25-27 Mayo. (2015) 443451 .

[21] L. Alameda, V. Calderôn, C. Junco, Â. Rodríguez, J. Gadea, S. Gutiêrrez-González, Characterization of gypsum plasterboard with polyurethane foam waste reinforced with polypropylene fibers, Mater. Constr. 66 (2016), https://doi. org/10.3989/mc.2016.06015 e100.

[22] S. Herrero del Cura, Influencia de la dosificación y granulometría del caucho de neumático fuera de uso (NFU) y de las dimensiones físicas en las propiedades térmicas, acústicas y mecánicas de placas de mortero de yeso y caucho, $\mathrm{PhD}$, Universidad Politécnica de Madrid, España, 2016. doí: 10.20868/UPM. thesis. 43070 .

[23] O. Gencel, J.J. del Coz Diaz, M. Sutcu, F. Koksal, F.P.A. Rabanal, G. MartinezBartera, W. Brostow, Properties of gypsum composites containing vermiculite and polypropylene fibers: numerical and experimental results, Energy Build. 70 (2014) 135-144, https://doi.org/10.1016/j.enbuild.2013.11.047.

[24] A. García Santos, Caracterización de compuestos de escayola reforzados, en relación con el tipo de refuerzo y la relación A/Y, Inf. La Constr. 56 (2004) 1931, https://doi.org/10.3989/ic.2004.v56.1493.436.

[25] A. Samková, P. Kulhavy, M. Pechočiaková, Possibilities to improve electromagnetic shielding of plaster composites adding carbon fibers, in: IOP Conf. Ser. Mater. Sci. Eng., 2017: p. UNSP 042025. doi:10.1088/1757-899X/ $254 / 4 / 042025$.

[26] J.A. Mohandesi, A. Sangghaleh, A. Nazari, N. Pourjavad, Analytical modeling of strength in randomly oriented PP and PPTA short fiber reinforced gypsum composites, Comput. Mater. Sci. 50 (2011) 1619-1624, https://doi.org, 10.1016/j.commatsci.2010.12.020.

[27] UNE-EN 13279-1:2009, Yesos de construcción y conglomerantes a base de yeso para la construcción. Parte 1: definiciones y especificaciones, 2009.

[28] UNE-EN 13279-2:2014, Yesos de construcción y conglomerantes a base de yeso para la construcción. Parte 2: Métodos de ensayo, 2014.

[29] RILEM RC 25-PEM, Recommended tests to measure the deterioration of stone and to assess theeffectiveness of treatment methods, Mater. Struct. 13 (1980) pp. 175-253.

[30] UNE-EN ISO 12572:2016, Prestaciones higrotérmicas de los productos y materiales para edificación. Determinación de las propiedades de transmisión de vapor de agua. Método de la taza, (2017).

[31] UNE-EN ISO 12572:2016, Placas de yeso laminado. Definiciones, especificaciones y métodos de ensayo, (2010).

[32] L.A. Mejía Betancourt, Elaboración de Compositos a Partir de Matriz Cementicia y Adicionamiento de Botellas PET y PVA en la Ciudad de Villavicencio Meta, Universidad Cooperativa de Colombia, 2017.

[33] L. Alameda, V. Calderón, J. Gadea, S. Gutiêrrez-González, Recycling of gypsum plasterboard lightened with polyurethane waste, An. Edif. 1 (2016) 33, https:// doi.org/10.20868/ade.2015.3037. 